\title{
Biology of the iberian chub (Squalius carolitertii) in an atlantic-type stream (river Lima basin-north Portugal). A preliminary approach
}

\author{
Hugo M. S. Maia ${ }^{1 *}$; Carla F. Q. Maia ${ }^{1}$; Daniel F. C. Pires $^{1} \&$ Alexandre C. N. Valente ${ }^{1,2}$ \\ 1 Departamento de Zoologia e Antropologia, Faculdade de Ciências da Universidade do Porto. Praça Gomes \\ Teixeira 4099-002 Porto, Portugal. \\ ${ }^{2}$ Unidade de Investigação em Eco-Etologia, Unidade FCT No 331/94. Instituto Superior de Psicologia Aplicada. \\ Rua Jardim do tabaco, 34, 1149-049 Lisboa, Portugal. \\ *Corresponding author: hmaia@fc.up.pt
}

\begin{abstract}
Biology of the iberian chub (Squalius carolitertii) in an atlantic-type stream (river Lima basin-north Portugal). A preliminary approach

The iberian chub (Squalius carolitertii) is an endemic species whose biology is yet largely unknown and which is catalogued as being endangered. Therefore more information about its biology is essential to develop appropriate management strategies. The Estorãos River population has been studied from December 1995 to March 2002 through regular electro-fishing surveys. Additionally, a fish trap installed in the river from November 2001 to July 2002 allowed for the collection of information on population movements and reproduction. The results revealed some fluctuations in the density estimates, though the Squalius carolitertii population in the Estorãos River is quite low. Six age classes $\left(0^{+}\right.$to $\left.5^{+}\right)$were identified. Iberian chub growth is isometric and can reach a final length of $33.5 \mathrm{~cm}$. Sexual dimorphism is evident, with males maturing earlier and at smaller sizes. An increase of the Iberian chub movements was detected from middle April onwards. These movements were related to the beginning of the reproductive period and were mainly correlated with the rise of water temperature. Our results indicate that the population characteristics do not differ substantially from those of other endemic chub populations in the Iberic peninsula.
\end{abstract}

Key words: Squalius carolitertii, density, growth, movement, reproduction, Portugal.

\section{RESUMEN}

Biología del bordallo (Squalius carolitertii) en un río atlántico (cuenca del río Lima, Norte de Portugal). Una aproximación preliminar

El bordallo (Squalius carolitertii) es una especie cuya biología es en gran parte desconocida y que está catalogada en peligro de extinción. El estudio de su biología es importante para la gestión de sus poblaciones y de su hábitat.

La población del río Estorãos (Cuenca del río Límia) ha sido estudiada de Diciembre de 1995 a Marzo de 2002 mediante muestreos con pesca eléctrica. Un sistema de redes utilizado de Noviembre de 2001 a Julio de 2002 permitió la obtención de información sobre los movimientos y parámetros reproductivos de la población. Los datos indican fluctuaciones de la densidad, a pesar de la población presentar valores muy bajos. Seis clases de edad $\left(0^{+}\right.$a $\left.5^{+}\right)$han sido identificadas. El crecimiento de Squalius carolitertii es isométrico y puede llegar a una talla final de 33,5 cm. El dimorfismo sexual es evidente y los machos maduran más temprano y con tallas inferiores a de las hembras. Un creciente de movimientos del bordallo ha sido encontrado a mediados del mes de Abril, lo que está de acuerdo con la fecha del período reproductivo y también con el incremento de la temperatura del agua. Nuestros datos indican que esta población no es muy distinta de otras poblaciones de bordallos endémicos de la península Ibérica.

Palabras clave: Squalius carolitertii, densidad, crecimiento, movimiento, reproducción, Portugal. 


\section{INTRODUCTION}

The Iberian chub, Squalius carolitertii (Doadrio, 1988), is an Iberian endemic species classified as of least concern (LC) in Portugal but considered threatened in Spanish waters (SPNRCN, 1991; Doadrio, 2001; ICN, 2004). Non-migratory fish species like the Iberian chub have drawn the attention of conservation agencies because they usually exhibit a high rate of decline linked to environmental perturbation. Therefore, it is essential to know everything about the species, especially its biology and genetics (Economidis, 2002).

Although inhabiting a large region, which includes the Douro, Mondego, Lima, Minho, and Lérez basins (Carmona \& Doadrio, 2000), only some ecological and biological population parameters such as density, biomass, age and growth patterns, and microhabitat use are available for the Douro and the Lima basins (Valente, 1990, 1993; Santos et al., 2004). In the systematic and genetic fields several papers have also been published (Doadrio, 1988; Coelho et al., 1995; Brito et al., 1997; Alves et al., 2002 and Sanjur et al., 2003).
The aim of this paper is to present the information obtained from fieldwork carried out from 1995 until 2002, namely density, age structure, growth, and condition factor patterns of the population inhabiting the Estorãos River. We also focus untreated aspects of the species' ecology, such as the reproductive period, the mobility pattern and its relationships with some environmental variables.

The results are mainly compared with already existant data from the Lima and Douro basins (Valente, 1990 and 1993), and with data provided by Lobón-Cerviá \& Sostoa (1987); FernándezDelgado \& Herrera (1995); Geraldes \& CollaresPereira (1995); Pires et al. (2000); Soriguer et al. (2000) and Bravo et al. (2001) for Squalius pyrenaicus, a sister species from southern Iberia.

\section{MATERIAL AND METHODS}

\section{Study area}

The Estorãos River is a small tributary (15 $\mathrm{km}$ long with a $65 \mathrm{~km}^{2}$ drainage basin) in the Lima River basin, in the Northwest region of Portugal (Fig. 1). It is a soft water stream

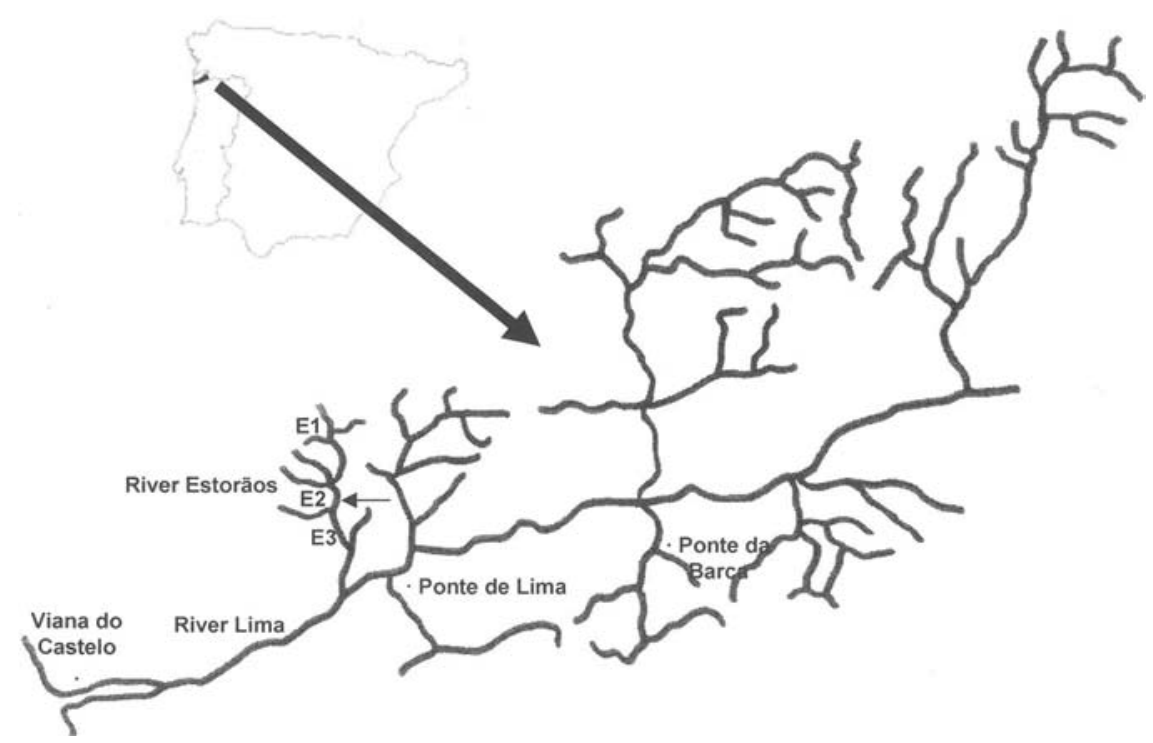

Figure 1. Study area in the Lima River basin in North Portugal. The location of the sampling sites in the Estorãos River (E1; E2; E3) and the fish trap (arrow) are shown. Área de estudio en la cuenca del río Lima al norte de Portugal. Se muestra la localización de los puntos de muestreo en el río Estorãos (E1; E2; E3) y la situación de la red (flecha). 
with slightly acidic water but with a good water quality (Fontoura, 1989; Valente, 1993). In addition, the lower stretch of the Estorãos River forms a complex drainage especially in the winter, when the floodplain is inundated, and is included in a regional wetland protected area. Besides the Iberian chub, the river fish community includes Anguilla anguilla, Barbus bocagei, Chondrostoma duriense, Chondrostoma oligolepis, Gasterosteus aculeatus, Petromyzon marinus, Platichthys flesus and Salmo trutta.

\section{Sampling}

The study of the Iberian chub population was conducted from December 1995 to March 2002. Electro-fishing (600 V, d. c. current) was carried out on a quarterly basis except from July 1998 to March 1999 and from December 2000 to March 2001. Three sampling sites (100 metres in length) were selected as representative of the aquatic habitats in the Estorãos River (sites E1, E2 and E3 located at $12 \mathrm{~km}, 5 \mathrm{~km}$ and 2.5 $\mathrm{km}$ respectively from the river mouth) (Fig. 1). These sites were closed with stop nets (mesh size $0.5 \mathrm{~cm}$ ) before sampling. All fish caught were anaesthetised (ethylenoglycol-monophenylether, $3 \mathrm{ml} / 10 \mathrm{~L}$ water) and then measured (fork length to the nearest $\mathrm{mm}$ ) and weighted (to the nearest $0.1 \mathrm{~g}$ ). Scale samples were collected during 2001 and 2002, according to Ombredane \& Baglinière (1992), for age determination. All fish were returned to the stream after recovering from the anaesthesia procedure.

\section{Density}

Density was estimated according to the twopass removal method with constant sampling effort maximum likelihood estimator of Seber \& Le Cren in Lobón-Cerviá (1991). When only one fish removal was carried out, other catch probability values were utilized. In such cases we used catch probability values obtained in other sampling sites where hydrological conditions, sampling season or site characteristics were similar (Lobón-Cerviá, 1991).
Table 1. Length-weight relationship for the iberian chub, Squalius carolitertii, caught in the fish trap and sampling sites in the 2001/02 season. Relación longitud-peso de los bordallos, Squalius carolitertii, pescados en la red y en los puntos de mиestreo en la estación 2001/02.

\begin{tabular}{lccccc}
\hline & & $\mathbf{a}$ & $\mathbf{b}$ & $\mathbf{r}^{\mathbf{2}}$ & $\mathbf{n}$ \\
\hline \multirow{3}{*}{ Fish Trap } & Females & 0.0116 & 3.06 & 0.95 & 63 \\
& Males & 0.0135 & 3.02 & 0.98 & 150 \\
& Undetermined & 0.0109 & 3.08 & 0.99 & 167 \\
\hline \multirow{3}{*}{ Sampling Sites } & E1 & 0.0202 & 2.86 & 0.98 & 48 \\
$(2001 / 02)$ & E2 & 0.0093 & 3.14 & 0.99 & 146 \\
& E3 & 0.0108 & 3.06 & 0.99 & 76 \\
\hline
\end{tabular}

\section{Age, condition, and growth}

Age classes were identified by scale reading. Total scale radius and distance from the focus to each annulus were measured on the lateroventral field of each fish scale. The lengths at age were back-calculated and used to estimate the Von Bertalanffy's growth equation parameters. The Fulton condition factor and the lengthweight relationship parameters were calculated. The true instantaneous growth rate was also determined. (Bagenal \& Tesch, 1978). We have utilized statistical procedures (T-test, Anova and Tukey's test-SPSS, Version 13.0) to analyse possible significant differences in the condition of the fish between sexes and sampling months (Sokal \& Rohlf, 1987).

\section{Mobility and reproduction}

A fish trap was installed in the Estorãos River to obtain additional information about population movements and the reproductive period (Fig. 1). The fish trap consisted of two fyke-nets (mesh size $0.5 \mathrm{~cm}$ ) which allowed the capture of all fish moving either upstream or downstream. All captured fish were measured (fork length to the nearest $\mathrm{mm}$ ) and weighted (to the nearest $0.1 \mathrm{~g}$ ). Sex was determined by abdominal compression. All fish were returned to the stream.

From November 2001 to June 2002 water temperature $\left({ }^{\circ} \mathrm{C}\right)$, water depth $(\mathrm{cm})$, and current velocity $(\mathrm{cm} / \mathrm{s})$ were measured three times a day (at 09:00, 17:00 and 22:00 hours) near the fish trap, and both fyke-nets were controlled for the 


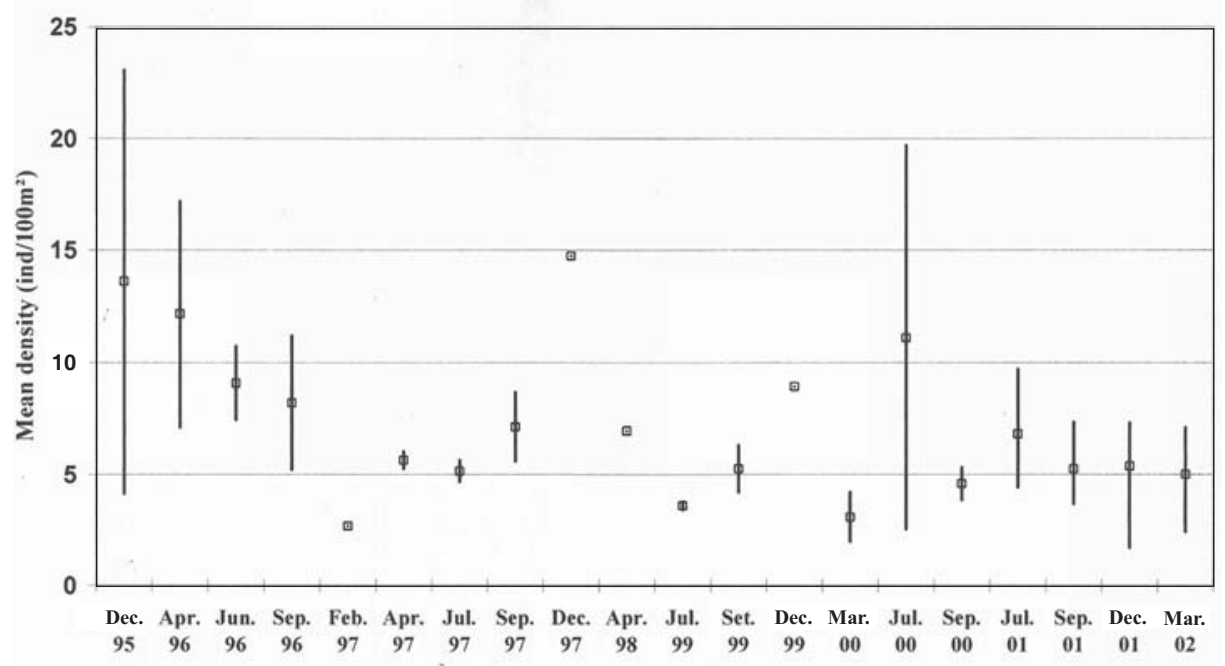

Figure 2. Evolution of the values of the estimated densities for the iberian chub, Squalius carolitertii, in the Estorãos River from December 1995 to March 2002. Mean, maximum, and minimum values observed are indicated for each sampling date (in February 97 , December 97, April 98, and December 99 only one site was sampled). Evolución de las densidades estimadas de bordallos, Squalius carolitertii, en el río Estorãos entre Diciembre de 1995 y Marzo de 2002. Los valores medios, máximos y mínimos observados se indican para cada fecha de muestreo (en Febrero 97, Diciembre 97, Abril 98 y Diciembre 99 sólo una de las localidades ha sido muestreada).

presence of fish. During extreme flood conditions the fish trap was removed.

The data was analysed to test for possible relationships between fish movements and water temperature $\left({ }^{\circ} \mathrm{C}\right)$, water flow $\left(\mathrm{m}^{3} / \mathrm{s}\right)$, current velocity $(\mathrm{cm} / \mathrm{s})$, and water depth $(\mathrm{cm})$. Linear regression parameters were calculated and the correlation coefficients obtained were transformed into a t-student ratio (Sokal \& Rohlf, 1987) to test the statistical significance of the relationships found. We also used the Spearman correlation test (Sokal \& Rohlf, 1987) to analyse the same relationships in the reproductive period.

\section{RESULTS}

\section{Density}

The estimated densities observed for the Squalius carolitertii population revealed some fluctuations with values ranging from a maximum of 23.08 ind/100 $\mathrm{m}^{2}$ in December 1995 (site E1) to a minimum of $1.69 \mathrm{ind} / 100 \mathrm{~m}^{2}$ in December 2001 (site E2) (Fig. 2). Nevertheless, in general, the estimated density values observed were quite low.

\section{Age, condition, and growth}

Six age classes $\left(0^{+}\right.$to $\left.5^{+}\right)$were identified by scale reading. The length-weight relationship parameters indicate an isometric growth (Table 1) and the Fulton's condition factor values (Table 2) confirm that fish were in good physiological conditions. The condition factor increased significantly in May (Anova, $p<0.0001$ and posthoc Tukey test, $p<0.05$, multiple comparisons between months) coinciding with the reproductive period, when the values determined for the mature fish were significantly higher (t-test, $p=$ 0.048) in males (Table 2).

The true instantaneous growth rate showed a normal decrease with age (Table 3 ).

The linear model has shown the best fit for the body and scale growth relationship $(L=4.815 \mathrm{~s} \times$ 2.2572; $n=122$ and $r^{2}=0.81 ; L=$ fork length; $s=$ scale length). Using back-calculated lengths at age (Table 3) we estimated the Von Bertalanffy growth equation parameters as follows:

$$
L t=33.5 \times\left[1-e^{(-0.09(t+0.49))}\right]
$$

where $L t=$ length at age $t ; t=$ age. The iberian 
Table 2. Mean Fulton's condition factor for the iberian chub, Squalius carolitertii, caught in the fish trap and sampling sites in the 2001/02 season. CF-Condition factor and standard deviation in brackets. Media del factor de condición de Fulton de los bordallos, Squalius carolitertii, pescados en la red y en los puntos de muestreo en la estación 2001/02. CF-Factor de condicion y desviación típica entre paréntesis.

\begin{tabular}{|c|c|c|c|c|c|c|c|c|c|c|c|c|}
\hline & & & $\begin{array}{c}\text { Jul } \\
01\end{array}$ & $\begin{array}{c}\text { Sep } \\
01\end{array}$ & $\begin{array}{c}\text { Nov } \\
01\end{array}$ & $\begin{array}{c}\text { Dec } \\
01\end{array}$ & $\begin{array}{c}\text { Jan } \\
02\end{array}$ & $\begin{array}{c}\text { Feb } \\
02\end{array}$ & $\begin{array}{c}\text { Mar } \\
02\end{array}$ & $\begin{array}{c}\text { Apr } \\
02\end{array}$ & $\begin{array}{c}\text { May } \\
02\end{array}$ & $\begin{array}{c}\text { Jun } \\
02\end{array}$ \\
\hline \multirow{6}{*}{ Fish Trap } & \multirow[t]{2}{*}{ Females } & $\mathrm{CF}$ & - & - & - & - & - & - & - & $\begin{array}{c}1.36 \\
(0.08)\end{array}$ & $\begin{array}{c}1.41 \\
(0.13)\end{array}$ & $\begin{array}{c}1.33 \\
(0.16)\end{array}$ \\
\hline & & $\mathrm{n}$ & - & - & - & - & - & - & - & 3 & 36 & 24 \\
\hline & \multirow[t]{2}{*}{ Males } & $\mathrm{CF}$ & - & - & - & - & - & - & - & $\begin{array}{c}1.39 \\
(0.09)\end{array}$ & $\begin{array}{c}1.44 \\
(0.13)\end{array}$ & $\begin{array}{c}1.38 \\
(0.15)\end{array}$ \\
\hline & & $\mathrm{n}$ & - & - & - & - & - & - & - & 11 & 103 & 36 \\
\hline & \multirow[t]{2}{*}{ Undetermined } & $\mathrm{CF}$ & - & - & $\begin{array}{c}1.29 \\
(0.00)\end{array}$ & $\begin{array}{c}1.25 \\
(0.05)\end{array}$ & $\begin{array}{c}1.22 \\
(0.11)\end{array}$ & $\begin{array}{c}1.14 \\
(0.03)\end{array}$ & $\begin{array}{c}1.32 \\
(0.18)\end{array}$ & $\begin{array}{c}1.32 \\
(0.15)\end{array}$ & $\begin{array}{c}1.39 \\
(0.17)\end{array}$ & $\begin{array}{c}1.30 \\
(0.10)\end{array}$ \\
\hline & & $\mathrm{n}$ & - & - & 1 & 6 & 3 & 3 & 17 & 78 & 37 & 22 \\
\hline \multirow{9}{*}{$\begin{array}{c}\text { Sampling } \\
\text { Sites } \\
(2001 / 02)\end{array}$} & \multirow{3}{*}{ E1 } & $\mathrm{CF}$ & 1.54 & 1.43 & - & 1.39 & - & - & 1.34 & - & - & - \\
\hline & & & $(0.06)$ & $(0.14)$ & - & $(0.10)$ & - & - & $(0.05)$ & - & - & - \\
\hline & & $\mathrm{n}$ & 11 & 10 & - & 20 & - & - & 7 & - & - & - \\
\hline & \multirow{3}{*}{ E2 } & $\mathrm{CF}$ & 1.25 & 1.25 & - & 1.10 & - & - & 1.21 & - & - & - \\
\hline & & & $(0.09)$ & (0.09) & - & $(0.35)$ & - & - & $(0.14)$ & - & - & - \\
\hline & & $\mathrm{n}$ & 72 & 46 & - & 7 & - & - & 21 & - & - & - \\
\hline & \multirow{3}{*}{ E3 } & $\mathrm{CF}$ & 1.25 & 1.20 & - & 1.21 & - & - & 1.28 & - & - & - \\
\hline & & & $(0.10)$ & $(0.12)$ & - & $(0.19)$ & - & - & $(0.08)$ & - & - & - \\
\hline & & $\mathrm{n}$ & 18 & 21 & - & 23 & - & - & 14 & - & - & - \\
\hline
\end{tabular}

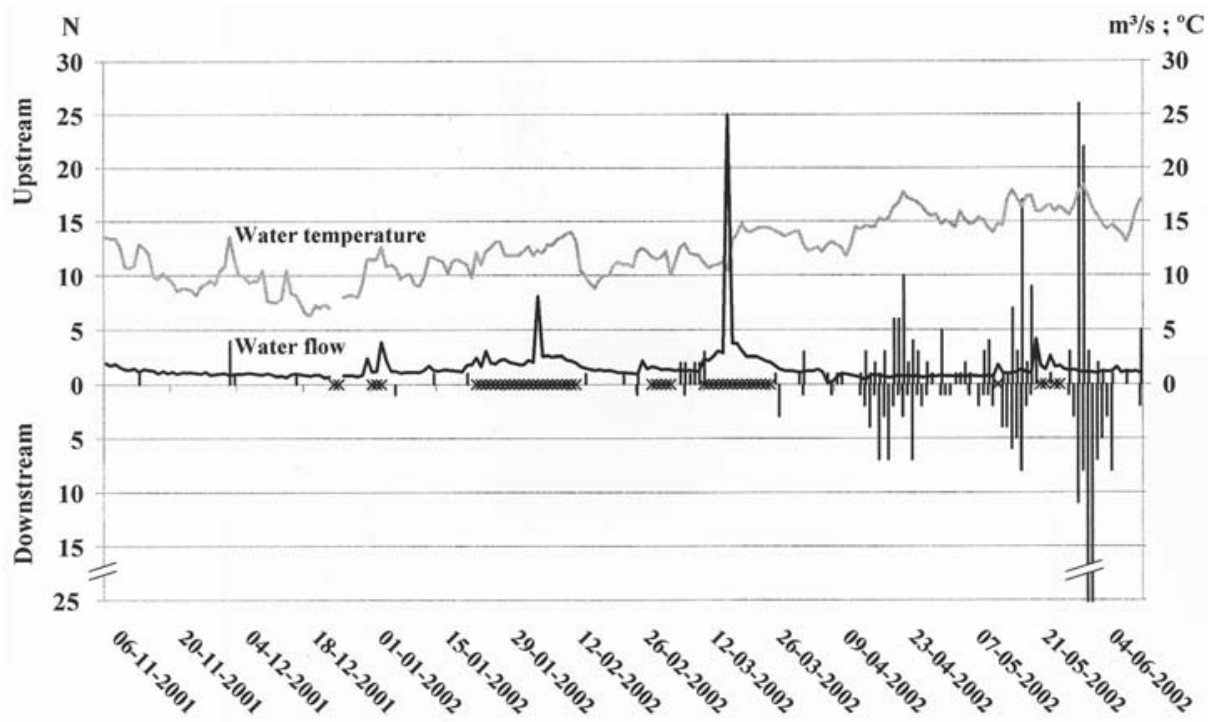

Figure 3. Number of iberian chub, Squalius carolitertii, caught in the fish trap (upstream-upper columns; downstream-lower columns) during the study period and the evolution of daily mean water temperature $\left({ }^{\circ} \mathrm{C}\right)$ and water flow $\left(\mathrm{m}^{3} / \mathrm{s}\right)$. Marks in the X-axis correspond to the period of system deactivation. Número de bordallos, Squalius carolitertii, pescados en la red (contracorrientecolumnas superiores; río abajo-columnas inferiores) durante el periodo de estudio y evolución de la temperatura media diaria del agua $\left({ }^{\circ} \mathrm{C}\right)$ y el flujo de agua $\left(\mathrm{m}^{3} / \mathrm{s}\right)$. Las marcas en el eje de abscisas se corresponden con los periodos de desactivación del sistema. 
Table 3. Mean back-calculated fork lengths at age (combined sexes), standard deviation in brackets and true mean instantaneous growth rates for the iberian chub, Squalius carolitertii, at different age intervals. Longitudes horquilla medias retrocalculadas (sexos combinados), desviación típica entre paréntesis y media de la tasa de crecimiento instantáneo real para los bordallos, Squalius carolitertii, a diferentes intervalos de edad.

\begin{tabular}{|c|c|c|c|c|c|c|c|c|c|c|c|}
\hline & & & & & Length & as at age & & & & & \\
\hline & & I & & II & & III & II & $\mathbf{V}$ & & $\mathbf{V}$ & n \\
\hline $1+$ & 4.18 & $(0.80)$ & & & & & & & & & 38 \\
\hline $2+$ & 4.56 & $(0.54)$ & 6.92 & (1.03) & & & & & & & 47 \\
\hline $3+$ & 4.45 & $(0.59)$ & 6.86 & (1.08) & 9.43 & $(1.08)$ & & & & & 22 \\
\hline $4+$ & 4.86 & $(0.78)$ & 7.36 & (1.44) & 9.73 & (1.12) & 11.64 & (1.12) & & & 13 \\
\hline $5+$ & 3.98 & $(0.28)$ & 5.64 & $(0.87)$ & 8.57 & $(2.52)$ & 11.63 & $(2.00)$ & 13.54 & $(1.43)$ & 2 \\
\hline Mean & 4.45 & $(0.69)$ & 6.94 & (1.12) & 9.49 & $(1.15)$ & 11.64 & (1.17) & 13.54 & $(1.43)$ & 122 \\
\hline $\bar{G}$ & & & & & & & & & & & 122 \\
\hline
\end{tabular}

chub can achieve an ultimate length of $33.5 \mathrm{~cm}$ but with a small growth rate.

\section{Mobility and reproduction}

The mean daily water temperature values ranged from 6.2 to $18.4{ }^{\circ} \mathrm{C}$ with a mean daily fluctuation of $1.3{ }^{\circ} \mathrm{C}\left(0.3\right.$ to $\left.2.5^{\circ} \mathrm{C}\right)$ (Fig. 3). Water discharge values ranged from 0.18 to $25.01 \mathrm{~m}^{3} / \mathrm{s}$ (Fig. 3). Water depth has shown important fluctuations during winter spates $(34.3$ to $215 \mathrm{~cm}$ ) and the current velocity ranged from 0.07 to $1 \mathrm{~m} / \mathrm{s}$.

The majority of the fish movements occurred from middle April onwards and were mainly correlated with the water temperature (Fig. 3 and Table 4) but did not show any preferred direction $(52 \%$ of the 391 fish were caught moving upstream). Fish movements and river flow and depth were also correlated but just for the downstream movements (Table 4).

Since the fish trap was operational during almost all the reproductive period it was possible to characterize this phase of the population's life cycle. Mature individuals appeared in late April (Fig. 4) and were caught until June 12, 2002 when the traps were removed. The length of

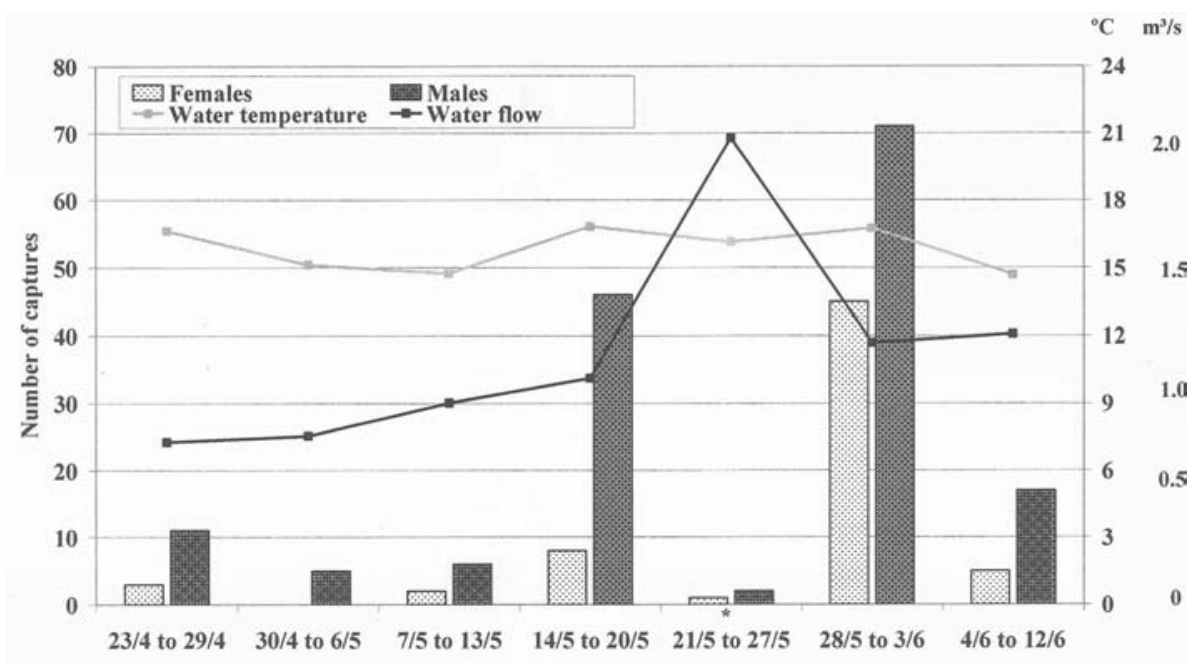

Figure 4. Number of mature iberian chub, Squalius carolitertii, caught in the fish trap during the reproductive period and evolution of the weekly mean water temperature and flow. ${ }^{*}$ Fish trap deactivated during three days. Número de bordallos, Squalius carolitertii, maduros pescados en la red durante el periodo reproductivo y evolución de la temperatura media semanal del agua y del flujo. * Red desactivada durante tres días. 


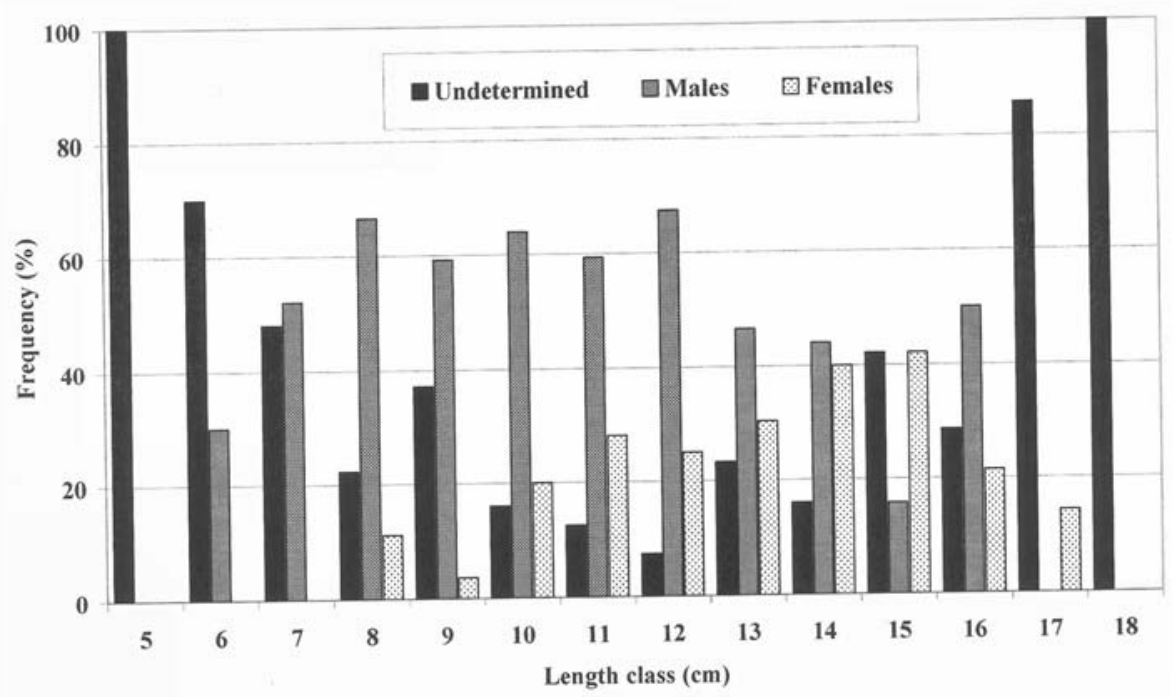

Figure 5. Length classes frequency distribution (\%) of the Iberian chub, Squalius carolitertii, caught in the fish trap during the reproductive period. Undetermined $(n=81)$, Females $(n=63)$, and Males $(n=153)$. Distribución de frecuencias $(\%)$ de bordallos, Squalius carolitertii, pescados en la red durante el periodo reproductivo por clases de talla. Indeterminados $(n=81) ;$ Hembras $(n=$ 63) y $\operatorname{Machos}(n=153)$.

females ranged from 8.1 to $17.6 \mathrm{~cm}$ and the one of males ranged from 6.6 to $16.9 \mathrm{~cm}$ (Fig. 5). In addition, one male with $24.3 \mathrm{~cm}$ was also caught in the fish trap. The only significant relationship between the number of mature males and females caught and the environmental parameters was found for water temperature (Spearman correlation test, $n=30 ; r=0.5$;

Table 4. T-student ratio values for the relationships between the number of Iberian chub, Squalius carolitertii, caught in each direction and the abiotic parameters. t-t-student ratio; DfDegrees of freedom; S-significance; $* *$ very significant $(p \leq$ $0.01)$; * slightly significant ( $p \leq 0.05)$; ns - not significant $(p>0.05)$. Valores $t$ de Student para las relaciones entre el número de bordallos, Squalius carolitertii, pescados en cada dirección y los parámetros abióticos. $t$-Valor de la $t$ de Student; Df-grados de libertad; $S$-nivel de significación; ** muy significativo $(p \leq 0.01)$; * ligeramente significativo $(p \leq 0.05)$; ns-no significativo $(p>0.05)$.

\begin{tabular}{cccccc}
\hline & & $\begin{array}{c}\text { Water } \\
\text { temperature }\end{array}$ & $\begin{array}{c}\text { Water } \\
\text { flow }\end{array}$ & $\begin{array}{c}\text { Current } \\
\text { velocity }\end{array}$ & Depth \\
\hline \multirow{4}{*}{ Downstream } & $t$ & 3.187 & 2.194 & 1.722 & 2.138 \\
& $\mathrm{~S}$ & $* *$ & $*$ & $\mathrm{~ns}$ & $*$ \\
& $\mathrm{Df}$ & 45 & 45 & 45 & 45 \\
\multirow{4}{*}{ Upstream } & $t$ & 5.018 & 0.217 & 0.522 & 0.474 \\
& $\mathrm{~S}$ & $* *$ & $\mathrm{~ns}$ & $\mathrm{~ns}$ & $\mathrm{~ns}$ \\
\hline
\end{tabular}

$t(n-2)=3.051 ; p=0.005)$. Most of the catch occurred when the water temperature was higher than $16.5^{\circ} \mathrm{C}$ (Fig. 4). Furthermore, according to our data the body length at the first maturation is inferior for the males, pointing out to an earlier sexual maturity (Fig. 5 and Table 3); apparently males mature during the second year of life $\left(1^{+}\right)$ whereas females mature during their third year of life $\left(2^{+}\right)$. Overall, the sex ratio is undoubtedly favourable to the males $\left(2.38 \sigma^{x}: 1\right.$ o).

\section{DISCUSSION}

The Squalius carolitertii density estimates in the Estorãos River are similar to the ones estimated from 1983 to 1986 for the same river (Valente, 1993), but higher than those estimated by Maia \& Valente (1999) for other tributaries of the Lima basin, with the only exception being the Froufe River (mean density of 12.92 ind $/ 100 \mathrm{~m}^{2}$ ). The estimated values are quite low when compared with other studies related to $S$. pyrenaicus (Bravo et al., 2001).

Furthermore, the age structure is similar to other previously studied Squalius carolitertii 
populations in tributaries of the Lima River (Valente, 1993), and similar to the ones for other Iberian sister species such as $S$. pyrenaicus (Fernández-Delgado \& Herrera, 1995; Geraldes \& Collares-Pereira, 1995; Lobón-Cerviá \& Sostoa, 1987 and Pires et al., 2000), although these authors have referred to some populations where fish attained 6 to 7 years of age.

The results for the length-weight relationship are in agreement with those referred to by Valente \& Alexandrino (1987) and Valente (1993). Also, an increase of the condition factor in the spring has been referred to by Fernández-Delgado \& Herrera (1995) for S. pyrenaicus. These authors stated that the somatic condition tended to be higher in females than in males, which contrast with the significantly higher somatic condition for the males that our results have revealed. However, Fernández-Delgado \& Herrera (1995) used the dry weight of eviscerated fish for their calculations of the somatic condition whereas, in this study, we utilized fresh weight. Nevertheless, the differences observed could be related to the final development of the gonads in the spring as observed by Soriguer et al. (2000) for $S$. pyrenaicus and the influence of the gonads' weight in the determination of the Fulton condition factor (Wootton, 1990). In addition, the sex-ratio referred to by Fernández-Delgado \& Herrera (1995) and Soriguer et al. (2000) for S. pyrenaicus (1 o: $\left.1 \sigma^{7}\right)$ reveals an equilibrium between sexes in contrast with the $2.38 \sigma^{x}$ : ? found in the Estorãos River for $S$. carolitertii. Such a sex ratio is difficult to explain, but the sexing procedure in our study did not involve visual inspection of the gonads. However, and as stated by Soriguer et al. (2000) for S. pyrenaicus, the number of immature fish is very high even in upper size classes where mature fish are expected and where the predominance of females is common in most cyprinids species (Mann, 1991).

The back-calculated lengths revealed values similar to those referred to by Valente (1993) for Iberian chub populations in other tributaries of the Lima River, except for the first year of growth where our results are higher. The estimated final length value is superior to those referred to by Valente (1990 and 1993) for tributaries of the
Lima and Douro basins, and even for the chub population inhabiting the upper Estorãos River stretches. Mean length values at age are within the range observed in other Iberian populations of S. pyrenaicus (Lobón-Cerviá \& Sostoa, 1987; Geraldes \& Collares-Pereira, 1995; FernándezDelgado \& Herrera, 1995 and Pires et al., 2000). Furthermore, the final length values referred to S. pyrenaicus (Lobón-Cerviá \& Sostoa, 1987 and Fernández-Delgado \& Herrera, 1995) are comparable to ours except in the case of the Sorraia River population (Geraldes \& CollaresPereira, 1995). It appears that the population of Squalius carolitertii in the Estorãos River could reach a bigger theoretical maximum length than the Portuguese populations of $S$. pyrenaicus, even though its growth rate is smaller.

Sexual maturity was reached by the males at a smaller size $(6.6 \mathrm{~cm}$ for the males and $8.1 \mathrm{~cm}$ for the females). Similar results have been obtained for S. pyrenaicus (Fernández-Delgado \& Herrera, 1995) and for S. torgalensis (Magalhães et al., 2003). Mann (1991) also stated that in most cyprinids females grow faster and became sexually mature later than males. FernándezDelgado \& Herrera (1995) and Geraldes \& Collares-Pereira (1995) had already observed that males matured at age $2^{+}$and females at age $3^{+}$in S. pyrenaicus. Only Magalhães et al. (2003) refer to the same age of maturation $\left(2^{+}\right)$for both sexes for $S$. torgalensis.

Our results also point out that water temperature is apparently the major factor associated with the fish movements as also stated by Maia \& Valente (2004) for Chondrostoma oligolepis. In addition, Santos et al (2002) found that river flow was the only factor significantly correlated to Iberian chub upstream daily movements in a fish lift in the Lima River. This is in contrast with our results that revealed the influence of the river flow only for the downstream movements. Santos et al. (2002) also stated that the Iberian chub major movements occurred from mid-April onwards when water temperature increases to values ranging from 12 to $14{ }^{\circ} \mathrm{C}$ which agrees with our results. Baras \& Cherry (1990) also found for the population of Barbus barbus in the Ourthe River, Belgium, that fish movements increased fo- 
llowing the rise of water temperature except for a few downstream movements caused by displacements due to high flow conditions. Accordingly, Rodriguez-Ruiz \& Granado-Lorencio (1992) found that water temperature is the major factor controlling migration and the periodicity of reproduction in three species of cyprinids in the Guadalete River (southwest of Spain). In conclusion, locomotion activity is enhanced by the variation of the environmental parameters, mainly the rise of water temperature, and is associated to the proximity of the reproductive period and the search for appropriated spawning grounds.

Overall, the results obtained in the present study suggest that the characteristics of this population do not differ substantially from those found for other Squalius carolitertii populations as well as for its sister species, S. pyrenaicus populations, even though Squalius carolitertii could reach a bigger theoretical maximum length than the Portuguese populations of S. pyrenaicus. Further research should then be directed to studies on the inventory and characterization of the spawning grounds in the Estorãos River and to the description of the Iberian chub spawning behaviour. Such information will certainly improve the knowledge of this species and will also allow for the adjustment of management strategies.

\section{ACKNOWLEDGMENTS}

This research was partially funded by the Portuguese Ministry of Science and Technology under the projects PRAXIS XXI 3/3.2/BIA/41/94 and PRAXIS XXI/P/BIA/10245/1998. This study was also partially funded by Ponte de Lima Municipality under the project Inventory of the fish community in the Protected Area of the Lagoons of Bertiandos and of São Pedro de Arcos. We thank the facilities granted by Direcção Geral das Florestas. We are especially grateful to Jorge Silva, Susana Carneiro, Pedro Correia, and António Sá Pereira for their help during field work. Last, thanks are due to the two anonymous reviewers whose contributions have greatly improved the final version of the manuscript.

\section{REFERENCES}

ALVES, M. J., M. J. COLLARES-PEREIRA, T. E. DOWLING \& M. M. COELHO. 2002. The genetics of maintenance of an all-male lineage in the Squalius alburnoides complex. J. Fish Biol., 60: 649-662.

BAGENAL, T. B. \& F. W. TESCH. 1978. Age and Growth. In: Methods for assessment of fish production in fresh waters. Bagenal, T. B. (Ed.): 101-136. IPB Handbook, 3. $3^{\text {rd }}$ Edition: Blackwell Scientific Publications, Oxford-London.

BARAS, E. \& B. CHERRY. 1990. Seasonal activities of female barbel Barbus barbus (L.) in the river Ourthe (Southern Belgium) as revealed by radiotracking. Aquatic Living Resources, 3: 283-294.

BRAVO, R., M. C. SORIGUER, N. VILLAR \& J. A. HERNANDO. 2001. The dynamics of fish populations in the Palancar stream, a small tributary of the river Guadalquivir, Spain. Acta Oecologica, 22: 9-20.

BRITO, R. M., J. BRIOLAY, N. GALTIER, Y. BOUVET \& M.M. COELHO. 1997. Phylogenetic relationships within genus Leuciscus (Pisces: Cyprinidae) in Portuguese freshwaters, based on mitochondrial DNA cytochrome b sequences. Molecular Phylogenetics and Evolution, 8: 435-442.

CARMONA, J. A. \& I. DOADRIO. 2000. Threatened fishes of the world: Leuciscus carolitertii Doadrio, 1988 (Cyprinidae). Environmental Biology of Fishes, 57: 96.

COELHO, M. M., R. M. BRITO, T. R. PACHECO, D. FIGUEIREDO \& A. M. PIRES. 1995. Genetic variation and divergence of Leuciscus pyrenaicus and L. carolitertii (Pisces: Cyprinidae). J. Fish Biol., 47: 243-258.

DOADRIO, I. 1988. Leuciscus carolitertii n. sp. from the Iberian Peninsula. Senckenbergiana biologica, 68: 301-309.

DOADRIO, I. (ed.) 2001. Atlas y libro rojo de los peces continentales de España. Dirección General de Conservación de la Naturaleza. Museo Nacional de Ciencias Naturales, Madrid, 364 pp.

ECONOMIDIS, P. S. 2002. Biology of rare and endangered non-migratory fish species: problems and constraints. In: Conservation of Freshwater Fishes: Options for the Future. Collares-Pereira, M. J.; Coelho, M. M. \& Cowx, I. G. (eds): 81-89. Blackwell Science. Fishing News Book, Oxford, London. 
FERNÁNDEZ-DELGADO, C. \& M. HERRERA. 1995. Age structure, growth and reproduction of Leuciscus pyrenaicus in an intermittent steam in the Guadalquivir river basin, Southern Spain. J. Fish Biol., 46: 371-380.

FONTOURA, A. P. (1989). Evolução da qualidade da água do rio Lima. Actas do Colóquio Lusoespanhol sobre Ecologia das Bacias Hidrográficas e Recursos Zoológicos. March 23-25, 1988. Faculty of Sciences, Porto, Portugal: 149-154.

GERALDES, A. M. \& M. J. COLLARES-PEREIRA. 1995. Preliminary insight into age and growth of the Iberian chub (Leuciscus pyrenaicus) in the Sorraia system. Folia Zoologica, 44: 159-165.

ICN. 2004. Livro vermelho dos vertebrados de Portugal -revisão. Classificação-resultados preliminares. Peixes. [on-line]. Retrieved October 12, 2004 from ICN on the World Wide Web: http://www.icn.pt/ documentos/livrovermelho/ClassifCritPeixes.pdf

LOBÓN-CERVIÁ, J. 1991. Dinâmica de Poblaciones de Peces en Rios. Pesca eléctrica y métodos de capturas sucesivas en la estima de abundancias. Monografias del Museo Nacional de Ciencias Naturales, 3: 1-156.

LOBÓN-CERVIÁ, J. \& A. SOSTOA. 1987. El crecimiento del Cacho (Leuciscus cephalus pyraenaicus Günther, 1862) en el río Jarama (cuenca del Tajo). Donãna, Acta Vertebrata, 14: 41-51.

MAGALHÃES, M. F., I. J. SCHLOSSER \& M. J. COLLARES-PEREIRA. 2003. The role of life history in the relationship between population dynamics and environmental variability in two Mediterranean stream fishes. J. Fish Biol., 63: 300-317.

MAIA, C. F. Q. \& A. C. N. VALENTE. 1999. The brown trout Salmo trutta L. populations in the river Lima catchment. Limnetica, 17: 119-126.

MAIA, H. \& A. VALENTE. 2004. Biology of the roach (Chondrostoma macrolepidotus) population in the Protected Area of the Lagoons of Bertiandos and of São Pedro de Arcos (Northern Portugal). Revista de Biologia (Lisboa), 22: 65-78.

MANN, R. H. K. 1991. Growth and Production. In: Cyprinid Fishes, Systematic, Biology and Exploitation. In: Winfield, I. J. \& Nelson, J. S. (eds.).: 456-482. Chapman \& Hall, London.

OMBREDANE, D. \& J. L. AGLINIÈRE, J. L. (1992). Les écailles et leurs utilisations en Écologie halieutique. In : Tissus durs et âge individuel des vertébrés. Baglinière, J. L., Castanet, J., Conand, F., Meunier, F. J. (eds.).: 151-192. Collo- que national, Bondy, France, 4-6 of March 1991. Colloques et Séminaires ORSTOM-INRA.

PIRES A. M., I. G. COWX \& M. M. COELHO. 2000. Life history strategy of Leuciscus pyrenaicus in intermittent streams of the Guadiana basin. Cybium, 24: 287-297.

RODRÍGUEZ-RUIZ, A. \& C. GRANADO-LORENCIO. 1992. Spawning period and migration of three species of cyprinids in a stream with Mediterranean regimen (SW Spain). J. Fish Biol., 41: 545-556.

SANJUR, O. I., J. A CARMONA \& I. DOADRIO. 2003. Evolutionary and geographical patterns within Iberian populations of the genus Squalius inferred from molecular data. Molecular Phylogenetics and Evolution, 29: 20-30.

SANTOS, J. M., M. T. FERREIRA, F. N. GODINHO \& J. BOCHECHAS. 2002. Performance of fish lift recently builds at the Touvedo Dam on the Lima River, Portugal. Journal of Applied Ichthyology, 18: 118-123.

SANTOS, J. M., F. N. GODINHO \& M. T. FERREIRA. 2004. Microhabitat use by Iberian nase Chondrostoma polylepis and Iberian chub Squalius carolitertii in three small streams, north-west Portugal. Ecology of Freshwater Fish, 13: 223-230.

SNPRCN. 1991. Livro vermelho dos vertebrados de Portugal. Vol. II - Peixes dulciaquícolas e migradores. Serviço Nacional de Parques, Reservas e Conservação da Natureza, Lisbon: 55 pp.

SOKAL, R. R. \& F. J. ROHLF. 1987. Introduction to Biostatistics. $2^{\text {nd }}$ Edition. W. H. Freeman and Co., San Francisco, 363 pp.

SORIGUER, M. C., R. BRAVO, C. VALLESPÍN, C. GÓMEZ-CAMA. \& J. A. HERNANDO. 2000. Reproductive strategies of two species of cyprinids in a stream with Mediterranean regimen (SW Spain). Arch. Hydrobiol., 148: 119-134.

VALENTE, A. C. N. 1990. As populações piscícolas do rio Febros. $1^{\circ}$ Congresso Internacional sobre o rio Douro. Observatório, 1: 421-437.

VALENTE, A. C. N. 1993. Biologia e dinâmica das populações de truta-de-rio, Salmo trutta L., da bacia hidrográfica do rio Lima. Ph.D Thesis, Universidade do Porto. 244 pp.

VALENTE, A. C. N. \& P. J. ALEXANDRINO. 1987. La ictiofauna del embalse de Bemposta (río Duero, Portugal). Actas IV Congreso Español de Limnología, Sevilla, España: 353-358.

WOOTTON, R. J. 1990. Ecology of Teleost Fishes. Chapman \& Hall. London, 386 pp. 